\title{
Marginal Lands: Concept, Assessment and Management
}

\author{
Shujiang Kang ${ }^{1}$, Wilfred M. Post ${ }^{1}$, Jeff A. Nichols ${ }^{1}$, Dali Wang ${ }^{1}$, Tristram O. West ${ }^{2}$, Varaprasad Bandaru ${ }^{2}$ \& \\ Roberto C. Izaurralde ${ }^{2}$ \\ ${ }^{1}$ Environmental Sciences Division, Oak Ridge National Laboratory, Oak Ridge, TN 37831, USA \\ ${ }^{2}$ Joint Global Change Research Institute, Pacific Northwest National Laboratory, College Park, MD 20740, USA \\ Correspondence: Shujiang Kang, Environmental Sciences Division, Oak Ridge National Laboratory, Oak Ridge, \\ TN 37831, USA. Tel: 1-865-574-5948. E-mail: kangs@ornl.gov
}

Received: February 4, 2013 Accepted: March 4, 2013 Online Published: April 15, 2013

doi:10.5539/jas.v5n5p129 URL: http://dx.doi.org/10.5539/jas.v5n5p129

\begin{abstract}
Marginal lands have received wide attention for their potential to improve food security and support bioenergy production. However, environmental issues, ecosystem services, and sustainability have been widely raised over the use of marginal land. Knowledge of the extent, location, and quality of marginal lands as well as their assessment and management are limited and diverse. There are many perceptions about what constitutes marginal lands and so clear definitions are needed. This paper provides a review of the historical development of marginal concept, its application and assessment. Challenges and priority research needs of marginal land assessment and management were also discussed.
\end{abstract}

Keywords: marginal land, land use, food security, bioenergy, land use, sustainability

\section{Introduction}

Marginal lands have received wide attention for their potential to increase food security and support bioenergy production (Brown, 1981; Tilman, Hill, \& Lehman, 2006; Food and Agriculture Organization (FAO), 2008; Robertson et al., 2008). Marginal lands are typically characterized by low productivity and reduced economic return or by severe limitations for agricultural use. They are generally fragile and at high environmental risk (Barbier, 1989; Wiegmann, Hennenberg, \& Fritsche, 2008). Currently, there is increasing interest in globally using marginal land for bioenergy biomass production in the face of limited arable land resources (Koonin, 2006; Milbrandt \& Overend, 2009; Vuichard, Ciais, \& Wolf, 2009). However, multiple concerns have been raised over environmental impacts, ecosystem services, and sustainability of marginal lands such as erosion, land degradation, biodiversity, and climate change mitigation (O'Connor et al., 2005; Intergovernmental Panel on Climate Change (IPCC), 2007; Searchinger et al., 2008; Fischer, Hizsnyik, Prieler, Shah, \& Velthuizen, 2009). The debate on marginal land use is a serious topic associated with the trilemma of land use planning: food security, bioenergy, and environmental concerns (Lal, 2009; Tilman et al., 2009).

Although the concept of marginal land has been broadly applied, a generalized understanding and knowledge of marginal land concept, assessment and management are limited and diverse. This paper provides a multi-disciplinary review of marginal land concepts and their development across time and space. We aim to encourage a holistic rethinking of marginal land use issues in order to optimize their use, sustain productivity, lower environmental risks, and enhance ecosystem services.

\section{Development of Marginal Land Concepts}

The concept of marginal lands has evolved across time, space, and discipline. The concept is often interchangeably used with other terms such as unproductive lands, waste lands, under-utilized lands, idle lands, abandoned lands, or degraded lands (FAO, 1976; Lal, 1991; Sugrue, 2008; Wiegmann et al., 2008). The meanings of marginal land and its application domains vary across regions, countries and organizations by emphasizing their different management goals (FAO, 1993; Baldock, Beaufoy, Brouwer, \& Godeschalk, 1996; Milbrandt \& Overend, 2009; Dale, Kline, Wiens, \& fargione, 2010; Tang, Xie, \& Geng, 2010; United States Department of Agriculture Natural Resources Conservation Services (USDA-NRCS, 2010).

Early concepts of marginal land emerged in the discipline of agricultural economics, and can be traced back to the $19^{\text {th }}$ century. Ricardo (1817) mentioned the idea of marginal lands in his land rent theory. Different marginal cost 
of lands would cause fluctuations in total production cost by shifting labor and capital, suggesting the farming trend between marginal lands and higher quality lands. The theory became the foundation of the marginal productivity theory. Hollander (1895) defined marginal lands as the poorest lands utilized above the margin of rent-paying land. Later, the concept of marginal land was systemically discussed by Peterson and Galbraith (1932) who examined the major variables associated with marginal lands, and proposed to dynamically determine locations of marginal lands. The three terms, physical marginal lands, production marginal lands, and economic marginal land were used under different backgrounds and concerns. In Europe, marginal lands have been defined as the land uses at the margin of economic viability (Strijker, 2005). Schroers (2006) defined more clearly an economically marginal land as "an area where a cost-effective production is not possible, under given site conditions, cultivation techniques, agricultural policies as well as macro-economic and legal conditions".

Physical marginality and production marginality of lands based on soil suitability and restrictions are often adopted by soil scientists and agronomists for the purpose of land use planning. Marginal lands generally refer to the areas not only with low production, but also with limitations that make them unsuitable for agricultural practices and ecosystem function (Heimlich, 1989; Hart, 2001). Some land limitations may not be directly associated with crop production, at least in the short term. Examples include highly erodible soil and ecologically sensitive areas. Prime farmland is defined as "the land that has the best combination of physical and chemical characteristics for producing food, feed, forage, fiber and oilseed crops". The opposite of prime farmland with restrictions of inherent soil characteristics are marginal lands (USDA-NRCS, 2010). Marginal agricultural land, marginal cropland, and marginal farming land are synonymously used in agricultural production terminology (G. Larson, Roloff, \& W. Larson, 1988; Niu \& Duiker, 2006). Marginal land concepts in agriculture are seldom applied to forestlands and grasslands.

High vulnerability of environment and ecological services of marginal lands have becomes issues of paramount concern (Baldock et al., 1996; Wood, Sebastian, \& Scherr, 2000; Dale et al., 2010). Soil erosion has been a major issue of decreasing soil fertility and yield due to loss of fertile topsoil, but its impact on nonpoint source (NPS) pollution (e.g., sediment and nutrients) became another focus of marginal land management (Charbonneau and Kondolf, 1993; USDA-NRCS, 2010). Land capability classification was widely applied to agricultural management and land conservation by Natural Resources Conservation Services of the U.S. Department of Agricultural (USDA-NRCS). Eight classes together with four subclasses are used for grouping soils primarily based on their capability to produce common cultivated crops and pasture plants without deterioration (USDA-NRCS, 2010) (Table 1). The land capability classes from IV to VIII characterized by high soil erosion or with some restrictions were generally categorized as marginal lands (Hamdar, 1999). Because of multiple important ecosystem services that would be impaired by utilization (e.g. biodiversity, wildlife, habitats and soil carbon storage), wetlands were usually classified as marginal lands. Sustainability reflecting long-term preservation trends of land functions has become a key component of marginal land concept (Wiegmann et al., 2008; Lal, 2009). Hence, the marginal land concept has evolved to meet multiple management goals and to incorporate the trade-offs of environmental protection, preservation of ecosystem services and long-term sustainability (Baldock et al., 1996; Krcmar, van Kooten, \& Vertinsky, 2005). P. Macdonald and A. Macdonald (2009) analyzed environmental limits and social-economic factors of marginal lands in the Highlands and Island of Scotland, and addressed the interactions between marginal landscapes and culture. Marginal land use planning would substantially alter communities and their development trends in the rural areas of developing countries (Sugrue, 2008). However, quantitative assessment of land marginality with respect to environmental suitability, ecological services, and sustainability is limited because of a lack of suitable metrics and criteria for multiple comparisons. 
Table 1. Land capability classification (LCC) derived from USDA-NRCS (2010)

\begin{tabular}{|c|c|}
\hline Class & Description \\
\hline 1 & Slight limitations that restrict their use \\
\hline 2 & Moderate limitations that restrict the choice of plants or that require moderate conservation practices \\
\hline 3 & $\begin{array}{l}\text { Severe limitations that restrict the choice of plants or that require special conservation practices, or } \\
\text { both }\end{array}$ \\
\hline 4 & $\begin{array}{l}\text { Very severe limitations that restrict the choice of plants or that require very careful management, or } \\
\text { both }\end{array}$ \\
\hline 5 & $\begin{array}{l}\text { Little or no erosion but have other limitations, impractical to remove, that restrict their use mainly to } \\
\text { pasture, rangeland, forestland, or wildlife habitat }\end{array}$ \\
\hline 6 & $\begin{array}{l}\text { Severe limitations that make them generally unsuitable for cultivation and that restrict their use mainly } \\
\text { to pasture, rangeland, forestland, or wildlife habitat }\end{array}$ \\
\hline 7 & $\begin{array}{l}\text { Very severe limitations that make them unsuitable for cultivation and that restrict their use mainly to } \\
\text { grazing, forestland, or wildlife habitat }\end{array}$ \\
\hline 8 & $\begin{array}{l}\text { Miscellaneous areas have limitations that preclude commercial plant production and that restrict their } \\
\text { use to recreational purposes, wildlife habitat, watershed, or esthetic purposes }\end{array}$ \\
\hline
\end{tabular}

\section{Marginal Lands for Food and Bioenergy Production}

Marginal lands provide necessary and candidate land resources for food production. Marginal lands account for about 36 percent of global agricultural land (1.3 billion ha), and support roughly one-third of the world's population (Wood et al., 2000). Cultivation of marginal lands is inevitable because of a shortage of prime agricultural lands in densely populated regions, as is essential in the developing countries due to the increasing demand on food (Laird, 1951; Nelson et al., 1997; FAO, 2008). To sustain crop production, marginal lands within the framework of land quality assessment program have become a major management target in countries with food shortages (FAO, 1993; Pieri, Dumanski, \& Hamlbin, \& Young, 1995). Several studies have suggested that enhancing food production will require the conversion of marginal lands to appropriate cropland management systems as well as restoration of degraded lands and ecosystems (Lal, 2004; Biggs, 2007). Twenty-five percent of recent increases in global wheat production were attributed to marginal lands in 1997 (Lantican, Pingali, \& Rajaram, 2003). Therefore, the importance of marginal lands for food production should be considered together with the requirement of land conservation and sustainability (Hoag \& Skold, 1996). Richardson, Bucks, \& Sadler (2008) believed that marginal land in large farms under conservation practices could be profitable and sustainable for management through a national analysis of Conservation Effects Assessment Programs (CEAP) in the U.S.

Marginal lands are regarded as crucial for the second generation of bioenergy crop production (i.e., lignocellulosic biomass crops). Second-generation bioenergy crops provide an attractive option for avoiding land competition between first-generation bioenergy crops (e.g. corn and sugarcane) and food crops (Tilman et al., 2006; the Royal Society, 2008). Vogel (1996) reported that the bioenergy crop, switchgrass [Panicum virgatum L.] can reach high biomass, and simultaneously avoid erosion on marginal lands. Marginal lands become competitive for bioenergy production when environmental, economic, and benefits are considered (Hill, Nelson, Tilman, Polasky, \& Tiffany, 2006). In the state of Tennessee, the U.S. alone, about 3.6 million ha of cropland eligible for CRP could be used for biomass production from cultivation of trees, native species, and improved grasses (Wells, Fribourg, Schlarbaum, Ammons, \& Hodges, 2003). This offers a high potential of biomass production for bioenergy. Additionally, utilizing marginal land resources such as riparian and roadway buffer strips, brownfield sites, and degraded agricultural land could produce enough feedstocks to meet a maximum of $22 \%$ of all the energy requirements (Gopalakrishnan, Negri, Wang, Wu, Snyder, \& Lafreniere, 2009). In China, about 45 million ha of marginal land could be used for biomass energy production (Tang et al., 2010). Using marginal land for bioenergy production in developing countries such as China and India would be the only solution to satisfy both food security and energy needs (Milbrandt \& Overend, 2009). The Worldwatch Institute (2006) estimated that about 100 million to 1 billion ha of marginal lands are theoretically available for production worldwide. Establishment of biofuel plantations on these soils would also restore degraded soils, sequester SOC, improve soil quality, and benefit environment (Lal, 2009; Fisher, 2010). Fargione, Hill, Tilman, Polasky, and Hawthorne (2008) conclude that bioenergy production on degraded and abandoned agricultural lands would cause little or no carbon debt. 
Pressure on biomass production for bioenergy is also driven by political goals in the European Union and the US. Globally, biofuels in the transportation sector are stated increase from a current rate of $2 \%$ up to $10 \%$ in 2020 . In the US, 36 billion gallons of renewable fuels will be required with the Energy Independence and Security Act by 2022 (U.S. Congress, 2007). Undoubtedly, policies with subsidy programs or incentives will accelerate a transition of marginal lands into bioenergy production.

\section{Marginal Lands Regarding Environmental Quality, Ecosystem Service and Sustainability}

Concerns have been frequently raised regarding the impacts of marginal land use on environment, ecosystem services and sustainability. To avoid soil loss and nonpoint source pollution, the Conservation Reserve Program (CRP) of the U.S. has encouraged farmers to retire marginal farmlands from production (USDA, 2006). CRP lands based on the Environmental Benefits Index (EBI) rankings benefit ecosystem services such as wildlife habitat and biodiversity. Hence, if such marginal lands are improved for food or bioenergy production, environmental quality and ecosystem services would be potentially at risk. Long-term monitoring and management are required for soil sustainability and minimizing environmental risks resulting from these land use changes (Blanco-Canqui, 2010). Degradation of land and soils is a serious issue as suggested by an analysis of these North American prairie grass systems for lignocellulosic biofuel production (Gutierrez \& Ponti, 2009). Some reports suggested that bioenergy production through land use change might not offset carbon emission (Righelato \& Spracklen, 2007; Searchinger et al., 2008). A systems study of sustainability is needed to target the multifaceted challenges of marginal land use (Gopalakrishnan et al., 2009; Interagency Biomass Research and Development Board, 2008).

However, a number of studies indicated that bioenergy crop production on marginal lands can benefit environmental quality, ecosystem service and sustainability. Because of relatively low soil organic carbon (SOC) content and weak ecosystem services in marginal lands, growing bioenergy crops on such lands can minimize the potential of long-term carbon debt and biodiversity loss in comparison to land clearing (Fargione et al., 2008; Tilman et al., 2009). The use of marginal lands for bioenergy production with sound management practices could potentially increase soil carbon sequestration, enhance soil and water quality and support ecosystem services (Lal, 2004; Mensah et al., 2003; Johnson, Franzluebbers, Weyers, \& Reicosky, 2007; Liebig, Schmer, Vogel, \& Mitchell, 2008). In the process of becoming productive, these soils could be an effective repository of $\mathrm{C}$ through the enhancement of SOC (Lal, 2004). Mensah, Schoenau, and Malhi (2003) reported that conversion of marginal land to perennial grassland for bioenergy biomass production would increase the soil carbon sink, reduce erosion, and enhance ecological functions. Previous studies on bioenergy crops summarized by Anderson-Teixeira, Davis, Masters, and Delucia (2009) and Blanco-Canqui (2010) indicated that bioenergy crops such as switchgrass and miscanthus can build up soil organic carbon and improve soil and environment after land conversion from restored prairie or CRP lands. Therefore, to evaluate the success of land management strategies in harmonizing the goals of economic, environment and ecosystem service, we need a comprehensive approach to addressing the intertwined issues of economic, carbon-uptake and structural diversity indicators (Gorissen, Buytaert, Cuypers, Dauwe, \& Pelkmans, 2010). Some methods of marginal land assessment derived from one or two land functions are inadequate for these multiple objectives. Accordingly, careful land use planning and management for marginal lands are required for sustaining production and environment (Barbier, 1989; Robertson et al., 2008).

\section{Dynamic Characteristics of Marginal Lands}

Many marginal lands are dynamic because of land use changes and social-economic impacts. Marginal lands are a transitional state of land resources, and very sensitive to natural processes and varied managements (Figure 1). Poor management of productive lands could cause land degradation. Marginal land can be enhanced or restored to productive lands by improving land functions. Another major driving force affecting the value of marginal lands is the market mechanism determined by socio-economic drivers. With the change in demand, the margin of land cultivation will advance or recede (Hollander, 1895). The decrease of land rent and increases of market demands change marginal profits and breakeven prices, and may finally lead to conversion of marginal lands into production. Places of economic paradox were employed to describe the dynamics and variability of marginal lands (Ritchie, 1950). Pollard (1997) summarized the trend of marginal land in Europe from the Middle Ages, and indicated that marginal lands have been significantly subject to economic development and food demands. Marginal land in Europe has been declining as a result of increasing labor costs and intensification of agriculture (Strijker, 2005). Certainly, policies, incentives and regulations are among driving variables causing land use change (Strijker, 2005; Perlack, 2007; James, Swinton, \& Thelen, 2010). All these driving variables obviously push farmers to reclaim or abandon marginal lands because of changing breakeven prices. Hence, marginal lands may not remain marginal, depending specific circumstances. Transitional characteristics of marginal lands would be critical for describing marginal land dynamics, and should be fully considered when marginal lands are assessed and managed. 


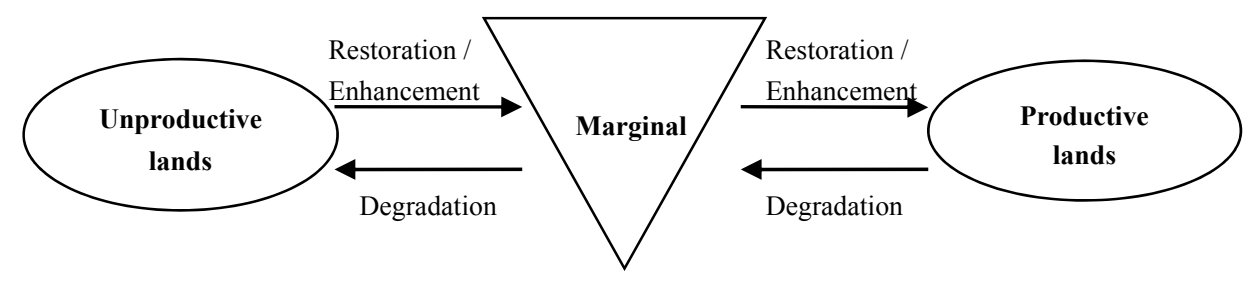

Figure 1. A transitional state of land uses - marginal lands

\section{Marginal Land Assessment}

Current methods for identifying marginal lands are qualitative and empirical, and some of them are very subjective. These methods reflect specific management goals on croplands across countries that vary with location and time. In the land use management framework of the Food and Agricultural Organization, United Nation (FAO, 1993), marginal land was simply classified as the lands with limitations such as erosion, wetlands, soil salinization, unfit for plant cultivation. Marginal farming land and prime farming land are used for farming suitability assessment by USDA-NRCS. Generally, the areas in land capability class IV-VIII that have severe limitations of production are classified as marginal lands (Hamdar, 1999). The farmlands registered in the Conservation Reserve Program (CRP) are generally treated as marginal lands to control soil erosion by the Food Security Act (Wells et al., 2003). Simply put, if one limiting factor of crop production such as soil, landscape and climate exists, the land is marginal (Biggs, 2007). Wastelands, paddy lands or lands fallow in winter are identified as marginal lands in China (Tang et al., 2010). Marginal land in the Marginal Lands Act 1940 of South Australia is simply classified as the land used to grow wheat, but unsuitable as the principle operations because of inadequate rainfall or other limitations (South Australia Land Act, 1940).

Some efforts for quantitative methods of marginal land assessment have been taken. On the basis of land capability classification, Larson et al. (1988) used a productivity index and an erosion resistivity index to identify marginal agricultural lands in Minnesota; however, other concerns such as wetland or soil limitations were not included. Smith, McDonald, and Thwaites (2000) developed a threat identification model for land sustainability assessment where marginal lands were identified with expert knowledge of local land management and their potential effects. Breuning-Masen, Reenberg, and Holst (1990) classified steep, wet and droughty soils as marginal agricultural land, and generated marginal land maps based on soil information in Denmark. Recent satellite data and historic information of land cover dynamics in Germany were used to detect the trend of abandonment of cultivation lands and further to identify marginal lands (Reger, Otte, \& Waldhardt, 2007). In these assessment methodologies of marginal lands, qualitative physical functions or restrictions of soil and landscape in addition to production were considered, but remain very limited in terms of quantitative assessment for multiple land functions. Social and economic factors are seldom included because of their high variability and lack of available data.

Mapping studies associated with marginal land assessment were also conducted at different spatial scales. Based on the detailed information of soil databases, marginal agricultural land in the seven states of the U.S was mapped by Niu and Duiker (2006). High risk of organic carbon loss in marginal lands was delineated for land use decision making. Potential soil productivity map developed by Nizeyimana et al. (2001) provides a solid basis of land use management through the nation of the U.S. This map roughly provided the locations of potential marginal production area in the U.S. Milbrandt and Overend (2009) identified 12 categories of marginal lands using climate and soil restrictions, and generated a map of marginal land in the Asia-Pacific Economic Cooperation (APEC) countries with the global agro-ecological zones system of the United Nations Food and Agriculture Organization (FAO). Based on soil productivity, land slope and climate, global marginal agricultural land is estimated and delineated, and they indicated that high availability of this land for bioenergy production (Cai, Zhang, \& Wang, 2011). Most of these mapping studies were mainly derived from soil and agricultural production analysis, but less on the aspects of environmental quality, ecosystem functions, and sustainability.

\section{Challenges and Needs of Marginal Land Use Management}

The concept of marginal land has evolved into a comprehensive term including multiple needs and concerns. With current knowledge, the concept of marginal lands can be further defined as the lands that are physically inaccessible or with soil and climate restrictions, or with high environmental risk and fragile ecosystem services, and with low production and therefore unprofitable. Following this concept, marginal lands are able to be assessed 
quantitatively and the most suitable management practices applied. However, challenges of marginal land assessment and management remain and several research issues need to be addressed.

\subsection{Criteria for Marginal Land Assessment and Management Recommendations}

None of the current methods for identifying marginal land are widely accepted. Existing methods for marginal land assessment are mostly qualitative, and only address some concerns and management goals; some of them are very subjective. Without effective criteria for identifying marginal lands, land resources cannot be well assessed and managed. For example, at a global scale, the amount of marginal lands varied among different studies, 1.3 billion ha, 36 percent of agricultural lands (Wood et al., 2000), about 100 million to 1 billion ha (The Worldwatch Institute, 2006), and 385-472 million ha (Campbell, Lobell, Genova, \& Field, 2008). Obviously, these numbers were estimated using different criteria to define marginal land. The constraints for marginal land assessment in developed countries are generally stricter than those in the developing countries (Sugrue, 2008; Wiegmann et al., 2008). While it may be challenging to establish global or unified marginal land criteria because of various management goals across region and countries, such criteria should be comparable and adjustable for a range of land use planning and policy making activities. As a major component of land resources assessment system, marginal land criteria should cover current requirements and concerns, and be derived from the existing criteria for water quality, air quality, soil and land quality or other tools for sustainable assessment. The criteria should also reflect the synergy of multiple land functions and management goals such as forested land, grasslands or rangelands, and other potential usable land resources besides crop land uses. Therefore, single index or criterion cannot fully meet these needs.

\subsection{Land-Informatics Directing Marginal Land Assessment and Management System}

Marginal land assessment and management involves multiple needs and concerns, and requires a systems approach to considering land functions and social-economic impacts. Major driving factors of marginal lands should include the demand of food supply and bioenergy, impacts of policies and incentives, and tradeoffs of environment, ecological services and sustainability. Current tools of soil quality and land quality assessment fail to meet the needs of marginal land management because of lack of comprehensive analysis of intertwined land functions and quantitative assessment. We outline here the essential ingredients of a land-informatics framework required to assist in the assessment, planning, monitoring of marginal lands (Figure 2). The framework incorporates land resources databases, land functions assessment, modeling and monitoring as well as decision-making tools. Best management practices and optimized production systems or scenarios of marginal lands can provide the synergistic analysis of land functions, needs and concerns on environment, ecosystem services and sustainability. Complimentarily, the land-informatics system is not only useful for marginal lands, but also can be extended to the other land resources management systems.

\subsection{Marginal Land Use Policy and Regulations}

Historically, land resources policies are associated with subsidy program and regulations in different regions and countries have played an important role in marginal land planning and management, for example, the Marginal Lands Acts 1940 in Australia (1940), the US-CRP implemented in 1985 (USDA, 2006), and the Energy Independence and Security Act of the US (U.S. Congress, 2007). These policies and regulations changed land use patterns and trends. However, most current policies on bioenergy biomass production have explicit bioenergy production goals, without any or with limited consideration of environmental effects, ecosystem functions and sustainability such as controlling nonpoint source pollutions (NPS) and mitigating climate change. Land use policy adjustment is critical (Strijker, 2005; Robertson et al., 2008; Acs et al., 2010). Meeting multiple goals with various tradeoffs in addition to production should be valued in the policies of marginal land use.

\subsection{Priority Research Needs on Marginal Lands}

Marginal land assessment and management are seriously challenged due to lack of clarified concepts, criteria, and effective quantification tools. The existing indices and indicators of soil quality and land quality that were developed for farming production are inadequate for assessing risks and tradeoffs of environment and ecosystem functions of marginal lands. The intertwined multiple land functions of marginal land further complicate assessment. Currently, the following research areas are critical for marginal land assessment and management:

- Developing and refining criteria of marginal lands. Criteria for marginal land assessment are urgent because of the current pressure of marginal land use transition for food and bioenergy crops. The existed indices of soil quality, land quality, environment and ecosystem indicated by Dumanski (1997) would provide a preliminary basis of criteria development. 
- Establishing a land-informatics framework. The land-informatics framework will be employed to direct research, management and monitoring of marginal lands. A hierarchical assessment system based on diverse land functions and concerns is recommended for development under the framework of land-informatics. The Land-informatics framework will also contribute to the knowledge-base of scientific decision making and policy considerations

- Quantifying land functions based on land processes. Because of land use change and the optimizing needs for environmental quality, ecosystem services and sustainability in marginal land production systems, effective quantification of land functions will be crucial. Studies on the dynamics, resistance and resilience of marginal land functions with management practices in addition to static land quality are highly required. This requires long-term monitoring of land processes using careful experimental designs.

- Understanding land functions resulting from the emerging bioenergy crop managements. Quantifying and monitoring land function changes caused by varied bioenergy crop managements in different regions will aid in optimizing bioenergy crops and management scenarios for marginal lands and reduce environmental risks and loss of ecosystem functions.

- Integrating social-economic factors into dynamic marginal land assessment tools for land use planning. Impacts of market and subsidies or incentives need explicit consideration of quantitatively determining dynamics of marginal lands.

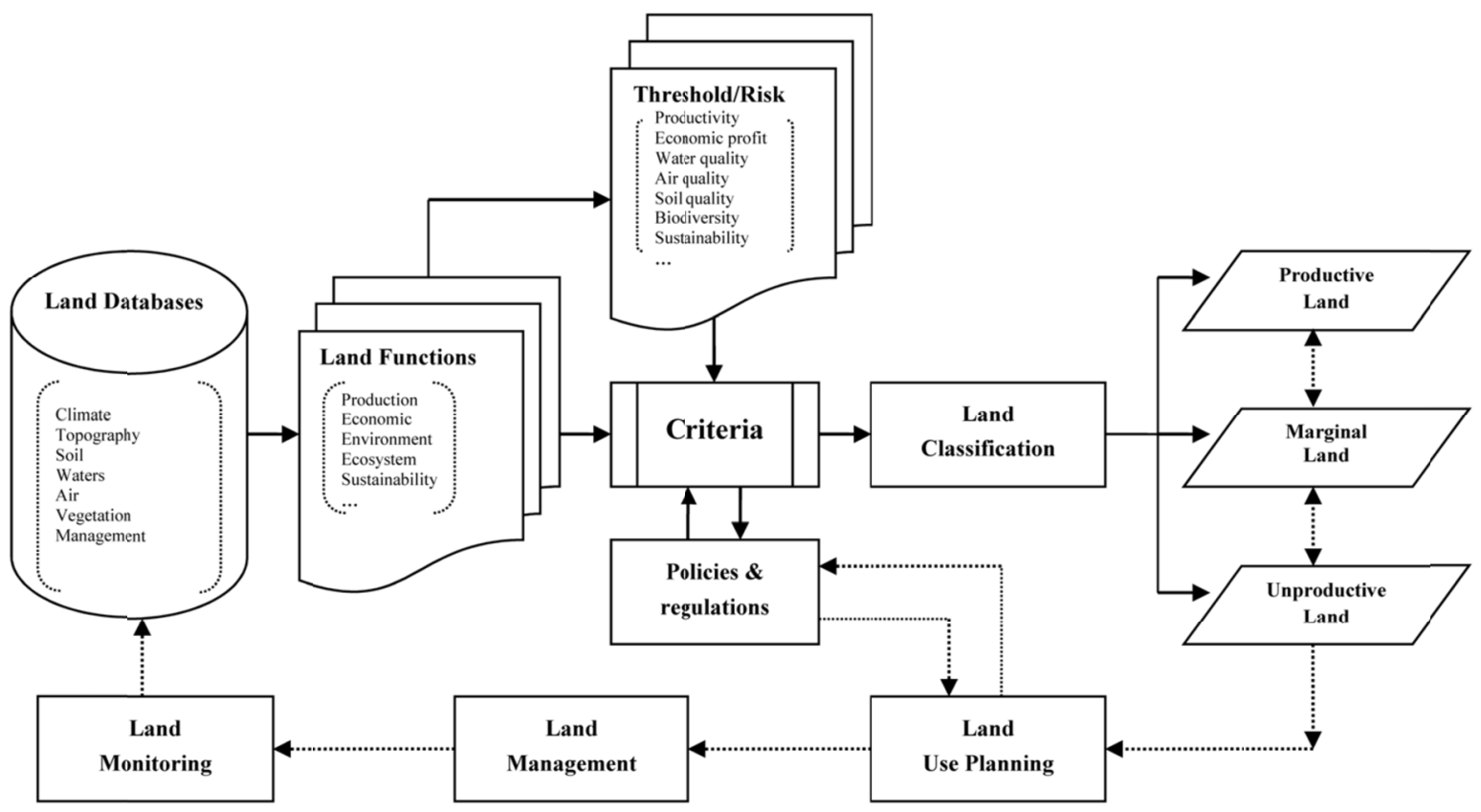

Figure 2. Land-informatics system directing assessment, management and monitoring of marginal land

\section{Summary}

The issue of marginal land use has triggered a wide discussion on future land use management for many countries and disciplines. Marginal lands play a critical role on the production of food and bioenergy under the growing pressure of limited land resources. However, a clarified concept and comprehensive understanding of marginal lands is needed that considers many intertwined land functions and social-economic impacts. Furthermore, effective comprehensive quantification assessment tools need continued development. Marginal land use planning can include multiple goals with best management practices and tradeoffs of concerns of environment, ecosystem services and sustainability under the framework of land-informatics. The debate on marginal lands will continue until our limited understanding of land functions and changes of management goals across time and space are improved. 


\section{Acknowledgement}

This research was supported by the US DOE Great Lakes Bioenergy Research Center (DOE BER Office of Science). Oak Ridge National Laboratory is managed by UT-Battelle, LLC, for the US Dep. of Energy under contract, DOE BER Office of Science DE-FC02-07ER64494.

\section{References}

Acs, S., Hanley, N., Dallimer, M., Gastonvb, K. J., Roberston, P., Wilson, P., \& Armsworth, P. R. (2010). The effect of decoupling on marginal agricultural systems: implication for farm incomes, land use and upland ecology. Land Use Policy, 27, 550-563. http://dx.doi.org/10.1016/j.landusepol.2009.07.009

Anderson-Teixeira, K. J., Davis, S., Masters, M. D., \& Delucia, E. H. (2009). Change in soil organic carbon under biofuel crops. GCB Bioenergy, 1, 75-96. http://dx.doi.org/10.1111/j.1757-1707.2008.01001.x

Baldock, D., Beaufoy, G., Brouwer, F., \& Godeschalk, F. (1996). Farming at the margins. London, UK: The Hague, IEEP, LEI-DLO.

Barbier, E. B. (1989). Sustaining agriculture on marginal land. Environment, 31, 12-40. http://dx.doi.org/10.1186/1471-2105-12-40

Bigges, A. (2007). The landscape and marginal cropping lands-inherent and induced. Tropical Grasslands, 41, 133-138.

Blanco-Canqui, H. (2010). Energy crops and their implications on soil and environment. Agron. J., 102, 403-419. http://dx.doi.org/10.2134/agronj2009.0333

Breuning-Madsen, H., Reenberg, A., \& Holst, K. (1990). Mapping potentially marginal land in Demark. Soil Use Manag., 6, 114-120. http://dx.doi.org/10.1111/j.1475-2743.1990.tb00819.x

Brown, L. R. (1981). World population growth, soil erosion, and food security. Science, 214, 995-1002. http://dx.doi.org/10.1126/science.7302578

Cai, X., Zhang, X., \& Wang, D. (2011). Land availability for biofuel production. Environ. Sci. Technol., 45, 334-339. http://dx.doi.org/ 10.1021/es103338e

Campbell, J. E., Lobell, D. B., Genova, R. C., \& Field, C. B. (2008). The global potential of bioenergy on abandoned agricultural lands. Environ. Sci. Technol., 42, 5791-5794. http://dx.doi.org/ 10.1021/es800052w

Charbonneau, R., \& Knodolf, G. M. (1993). Land use change in California, USA: nonpoint source water quality impacts. Environ. Manag., 17, 453-460. http://dx.doi.org/10.1007/BF02394661

Dale, V. H., Kline, K. L., Wiens, J., \& Fargione, J. (2010). Biofuels: implications for land use and biodiversity. Biofuels and Sustainability Reports, Ecological Society of America.

Dumanski, J. (1997). Criteria and indicators for land quality and sustainable land management. ITC J., 3, 217-222.

Fargione, J., Hill, J., Tilman, D., Polasky, S., \& Hawthorne, P. (2008). Land clearing and biofuel carbon debt. Science, 319, 1235-1238. http://dx.doi.org/10.1126/science.1152747

Fischer, G., Hizsnyik, E., Prieler, S., Shah, M., \& Velthuizen, H. (2009). Biofuels and food security - implication of accelerated biofuels production. Summary of the OFID study prepared by IIASA, Vienna, Austria.

Fisher, M. (2010). Sustainable bioenergy: fueling biomass plants without degrading the land. CSA News.

Food and Agricultural Organization of United Nations (FAO). (1976). A framework for land evaluation. FAO Soils Bulletin No. 32. FAO, Rome, Italy.

Food and Agricultural Organization of United Nations (FAO). (1993). FESLM: an international framework for evaluating sustainable land management. World Resources Report 73. FAO, Rome, Italy.

Food and Agricultural Organization of United Nations (FAO). (2008). A framework for bioenergy environmental impact analysis. Öko-Institut, Ifeu-Institute, Copernicus Institute financed by the Food and Agriculture Organization (FAO), Rome.

Gopalakrishnan, G., Negri, M. C., Wang, M., Wu, M., Snyder, S. W., \& Lafreniere, L. (2009). Biofuels, land, and water: A systems approach to sustainability. Environ. Sci. Technol, 43, 6094-6100. http://dx.doi.org/10.1021/es900801u

Gorissen, L, Buytaert, V., Cuypers, C., Dauwe, T., \& Pelkmans, L. (2010). Why the debate about land use change should not only focus on biofuels. Environ. Sci. Technol., 44, 4046-4049. http://dx.doi.org/10.1021/es903036u 
Gutierrez, A. P., \& Ponti, L. (2009). Bioeconomic sustainability of cellulosic biofuel production on marginal lands. Bulletin of Science, Technology \& Society, 29, 213-225. http://dx.doi.org/ 10.1177/0270467609333729

Hamdar, B. (1999). An efficiency approach to managing Mississippi's marginal land based on the conservation reserve program (CRP). Resour. Conserv. Recy., 26, 15-24.

Hart, J. F. (2001). Half a century of cropland change. Geographical Review, 91, 525-543. Http://dx.doi.org/10.1111/j.1931-0846.2001.tb00239.x

Heimlich, R. E. (1989). Productivity and erodibility of U.S. cropland. Agricultural Economic Report 604, U.S. Dept. of Agriculture, Economic Research Service.

Hill, J., Nelson, E., Tilman, D., Polasky, S., \& Tiffany, D. (2006). Environmental, economic, and energetic costs and benefits of biodiesel and ethanol biofuels. PNAS, 103, 206-210. http://dx.doi.org/10.1073_iti3006103

Hoag, D. L., \& Skold, M. D. (1996). The relationship between conservation and sustainability. J. Soil Water Conserv., 51, 292-295.

Hollander, J. H. (1895). The concept of marginal rent. Q. J. Econ., 9, 175-187.

Interagency Biomass Research and Development Board. (2008). Increasing feedstock production for biofuels: economic drivers, environmental implications, and the role of research, Washington D.C.

Intergovernmental Panel on Climate Change (IPCC). (2007). Chapter 5: food, fiber, and forest products. IPCC fourth Assessment report (AR4) - Climate change 2007: impacts, adaptation and vulnerability. Cambridge, UK: Cambridge University Press.

James, L. K., Swinton, S. M., \& Thelen, K. D. (2010). Profitability analysis of cellulosic energy crops compared with corn. Agron. J., 102, 675-687. http://dx.doi.org/ 10.2134/agronj2009.0289

Johnson, J. M. F., Franzluebbers, A. J., Weyers, S. L., \& Reicosky, D. C. (2007). Agricultural opportunities to mitigate greenhouse gas emission. Environ. Pollut., 150, 107-124. http://dx.doi.org/10.1016/j.envpol.2007.06.030

Koonin, S. E. (2006). Getting serious about biofuels. Science, 311, 435. http://dx.doi.org/10.1126/science.1124886

Krcmar, E., van Kooten, G. C., \& Vertinsky, I. (2005). Managing forest and marginal agricultural land for multiple tradeoffs: compromising on economic, carbon and structural diversity objectives. Ecol. Model., 185, 451-468. http://dx.doi.org/10.1016/j.ecolmodel.2004.12.014

Laird P. (1951). Problems of marginal land farming. Nature, 168, 457-458. Http://dx.doi.org/10.1016/j.ecolmodel.2004.12.014

Lal, R. (1991). Tillage and agricultural sustainability. Soil till. Res., 20, 133-146. http://dx.doi.org/10.1016/0167-1987(91)90036-W

Lal, R. (2004). Soil carbon sequestration to mitigate climate change. Geoderma, 123, 1-22. http://dx.doi.org/10.1016/j.geoderma.2004.01.032

Lal, R. (2009). Soil and World food security. Soil Till. Res., 102, 1-4. http://dx.doi.org/10.1016/j.still.2008.08.001

Lantican, M. A., Pingali, P. L., \& Rajaram, S. (2003). Is research on marginal lands catch up? The case of unfavorable wheat growing environments. Agr. Econ., 29, 353-361. http://dx.doi.org/10.1111/j.1574-0862.2003.tb00171.x

Larson, G. A., Roloff, G., \& Larson, W. E. (1988). A new approach to marginal agricultural land classification. $J$. Water Conserv., 43, 103-106.

Liebig, M. A., Schmer, M. R., Vogel, K. P., \& Mitchell, R. B. (2008). Soil carbon storage by switch grass grown for bioenergy. Bioenergy Research, 1, 215-222. http://dx.doi.org/10.1007/s12155-008-9019-5

Macdonald, P., \& Macdonald, A. (2009). Marginal lands? An overview of the environmental contexts of cultural landscapes in the highlands and islands of Scotland. International Journal of Heritage Studies, 15, 108-141. http://dx.doi.org/10.1080/13527250902890605

Marginal Lands Acts. (1940). An act to confer powers upon the minister of lands in relation to the settlement of marginal lands, Australia. 
Mensah, F, Schoenau, J. J., \& Malhi, S. S. (2003). Soil carbon changes in cultivated and excavated land converted to grasses in east-central Saskatchewan. Biogeochemistry, $63, \quad 85-92$. http://dx.doi.org/10.1023/A:1023369500529

Milbrandt, A., \& Overend, R. P. (2009). Assessment of biomass resources from marginal lands in APEC economics. The APEC Energy Working Group under EWG 11/2008A.

Nelson, M., Dudal, R., Gregerson, H., Jodha, N., Nyamai, D., Groenewold, J. P., .. Kassam, A. (1997). Report of the study on CGIAR research priorities for marginal lands. TAC Working Document, CGIAR, Technical Advisory Committee, Rome, Italy.

Niu, X., \& Duiker, S. W. (2006). Carbon sequestration potential by afforestation of marginal agricultural land in the Midwestern U.S. Forest Ecol. Manag., 223, 415-427. http://dx.doi.org/10.1016/j.foreco.2005.12.044

Nizeyimana, E. L., Petersen, G. W., Imhoff, M. L., Sinclair, H. R., Waltman, S. W., Reed-Margetan, D. S., ... Russo, J. M. (2001). Assessing the impact of land conversion to urban use on soils with different productive levels in the USA. Soil Sci. Soc. Am. J., 65, 391-402. http://dx.doi.org/10.2136/sssaj2001.652391x

O’Connor, G. A., Elliott, H. A., Basta, N. T., Bastian, R. K., Pierzynski, G. M., Sims, R. C., \& Smith, J. E. (2005). Sustainable land application: an overview. J. Environ. Qual., 34, 7-17. http://dx.doi.org/10.2134/jeq2005.0007

Perlack, R. D. (2006). Biomass Feedstock Resource Availability: Interim Update to the Billion-Ton Vision Report, submitted to the U.S. Department of Energy, Office of the Biomass Program.

Peterson, G. M., \& Galbraith, J. K. (1932). The concept of marginal land. J. Farm Econ., 14, 295-310.

Pieri, C. J., Dumanski, J., Hamblin, A., \& Young, A. (1995). Land quality indicators. World Bank Discussion Papers 315. The World Bank, Washington, DC.

Pollard, S. (1997). Marginal Europe: the contribution of marginal lands since the middle ages. Clarendon Press.

Reger, B., Otte, A., \& Waldhardt, R. (2007). Identifying patterns of land-cover change and their physical attributes in a marginal European landscape. Landscape Urban Plan, 81, 104-113. http://dx.doi.org/10.1016/j.landurbplan.2006.10.018,

Ricardo, D. (1817). On the principles of political economy and taxation. London, UK: J. M. Dent \& sons, ltd.

Richardson, C. W., Bucks, D. A., \& Sadler, E. J. (2008). The conservation effects assessment project benchmark watersheds: synthesis of preliminary findings. J. Soil Water Conserv, 63, 590-604.

Righelato, R., \& Spracklen, D. V. (2007). Carbon mitigation by biofuels or by saving and restoring forests? Science, 317, 902. http://dx.doi.org/10.1126/science.1141361

Ritchie, J. M. (1950). Some observations on problems of hill and marginal land. Econ. J., 60, 740-752.

Robertson, G. P., Dale, V. H., Doering, O. C., Hamburg, S. P., Melillo, J. M., Wander, ... Wilhelm, W. W. (2008). Sustainable biofuels redux. Science, 322, 49-50. http://dx.doi.org/10.1126/1161525

Royal Society. (2008). Sustainable biofuels: prospects and challenges. Science policy section, the Royal Society, 6-9 Carlton House Terrace. London, UK.

Schroers, J. O. (2006). Towards the development of marginal land use depending on the framework of agricultural market, policy and production techniques. University of Giessen, Germany.

Seachinger, T., Heimlich, R., Houghton, R. A., Dong, F., Elobeid, A., Fabiosa, J., ... Yu, T. (2008). Use of U.S. croplands for biofuels increase greenhouse gasses through land-use change. Science, 319, 1238-1240. http://dx.doi.org/10.1126/science.1151861

Smith, C. S., McDonald, G. T., \& Thwaites, R. N. (2000). TIM: assessing the sustainability of agricultural land management. J. Environ. Manage., 60, 267-355. http://dx.doi.org/10.1006/jema.2000.0384

South Australia Marginal Lands Act. (1940). An act to confer powers upon the minister of lands in relation to the settlement of marginal lands.

Strijker, D. (2005). Marginal lands in Europe - causes of decline. Basic Appl. Ecol., 6, 99-106. http://dx.doi.org/10.1016/j.baae.2005.01.001

Sugrue, A. (2008). Bioenergy production on marginal and degraded land: the potential social impacts. Draft paper for presentation to the joint international workshop on high nature value criteria and potential for sustainable use of degraded land. Paris, France. 
Tang, Y., Xie, J., \& Geng, S. (2010). Marginal land-based biomass energy production in China. J. Integr Plant Bio., 52, 112-121. http://dx.doi.org/10.1111/j.1744-7909.2010.00903.x

Tilman, D., Hill, J., \& Lehman, C. (2006). Carbon-negative biofuels from low-input high-diversity grassland biomass. Science, 314, 1598-1600. http://dx.doi.org/10.1126/science.1133306

Tilman, D., Socolow, R., Foley, J.A., Hill, J., Larson, E., Lynd, L., ... Williams, R. (2009). Beneficial biofuels the food, energy, and environment trilemma. Science, 325, $270-271$. http://dx.doi.org/10.1126/science. 1177970

United States Congress. (2007). Energy Independence and Security Act of 2007. Public Law No: 110-140

United States Department of Agriculture (USDA). (2006). Agricultural conservation reserve protection program (CRP). USDA Farm Service Agency, Washington, DC.

United States Department of Agriculture- Natural Resources Conservation Services (USDA-NRCS). (2010). National soil survey handbook 430-VI. Retrieved from http://soils.usda.gov/technical/handbook/

Vogel, K. P. (1996). Energy production from forages (or American agriculture-back to the future). J. Soil Water Conserv., 51, 137

Vuichard, N., Ciais, P., \& Wolf, A. (2009). Soil carbon or biofuel production: new land-use opportunities for mitigating climate over abandoned Soviet farmlands. Environ. Sci. Technol, 43, 8678-8683. http://dx.doi.org/10.1021/es901652t

Wells, G. R., Fribourg, H. A., Schlarbaum, S. E., Ammons, J. T., \& Hodges, D. G. (2003). Alternate land uses for marginal soils. J. Soil Water Conserv., 58, 73-81.

Wiebe, K. (2003). Land quality, agricultural productivity, and food security: Biophysical processes and economic choices at local, regional and global levels. Edward Elgar Publishing Limited, Massachusetts 01060. USA.

Wiegmann, K., Hennenberg, K. J., \& Fritsche, U. R. (2008). Degraded land and sustainable bioenergy feedstock production. Oko-Institut, Darmstadt Office. Joint International Workshop on High Nature Value Criteria and Potential for Sustainable Use of Degraded Lands, Paris, France.

Wood, S., Sebastian, K., \& Scherr, S. J. (2000). Pilot Analysis of Global Ecosystems: agroecosystems. International Food Policy Research Institute and World Resources Institute, Washington, DC.

Worldwatch Institute. (2006). Biofuels for transportation: Global potential and implications for sustainable agriculture and energy in 21st century. Prepared for the Federal Ministry of Food, Agriculture and Consumer Protection (BMELV), Germany in cooperation with GTZ and FNR. Washington D.C. 